\title{
Michał Kaczkowski i jego praca 0 chorobie cholera morbus zwanej
}

\author{
Michał Kaczkowski and his work On the disease called \\ cholera morbus
}

\section{Summary}

The appearance of cholera in Poland was a significant epidemiological problem. One of the first works devoted to the etiology, the search for methods of therapy as well as the necessary hygienic and sanitary measures to prevent the spread of this disease was written in 1830 by Michał Kaczkowski. His work, despite the passage of years, still deserves attention.

Słowa kluczowe: Michał Kaczkowski, choroby epidemiczne, cholera, XIX w., historia medycyny

Keywords: Michał Kaczkowski, epidemic diseases, cholera, 19th century, history of medicine

\section{Wprowadzenie}

Wiadomości o autorze tej niewielkiej, liczącej zaledwie 29 stron książeczki są nad wyraz skąpe. Był jednym z trzech synów Grzegorza Kaczkowskiego, porucznika wojska polskiego działającego intensywnie w ruchu patriotycznym w czasie wojny w obronie Konstytucji 3 Maja, a także powstania kościuszkowskiego, oraz Marii z domu Zielińskiej ${ }^{1}$. Urodził się w 1810 r. w Krzemieńcu i tam też ukończył słyn-

1 Wspomnienie z papierów pozostałych po ś.p. Karolu Kaczkowskim generat sztab-lekarzu wojsk polskich ułożył Tadeusz Oksza-Orzechowski, t. II, Gubrynowicz i Schmidt, Lwów 1876, s. 246. 
ne Liceum Krzemienieckie ${ }^{2}$ założone 13 października 1805 r. przez Tadeusza Czackiego ${ }^{3}$. Karol Estreicher, notując jego dziełko w swojej Bibliografii staropolskiej ${ }^{4}$, dodaje kilka słów: „z Kutty na Wołyniu, zmarł w 1848 roku" . Popełnia przy tym drobną nieścisłość, gdyż jak podaje Józef Peszke w Wielkiej Encyklopedyi Illustrowanej ${ }^{6}$ - był jeszcze inny lekarz tego samego imienia i nazwiska rzeczywiście pochodzący z Kuty, a o Michale Kaczkowskim wspomina tylko, iż był on „rodem z Wołynia”". Stanisław Kośmiński zamieszcza w swoim biogramie ponadto, iż ,uzyskawszy w 1829 roku stopień doktora medycyny w Wilnie praktykował w powiecie włodzimierskim na Wołyniu gdzie słusznej używał wziętości, umarł w Horohowie w 1849 roku”. Data zgonu również nie jest pewna. I tak, biogram w S. Orgelbranda

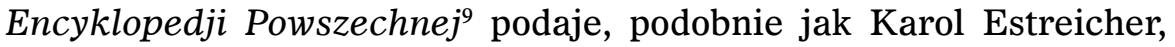
rok 1848, natomiast Piotr Szarejko, odwołując się do notatek Józefa Bielińskiego, wskazuje na rok $1850^{10}$. Tę samą datę podaje również w krótkim biogramie Witold Lisowski, lecz dla odmiany jako datę urodzenia wymienia rok $1808^{11}$. Istnieją również dane, że prowadził przez pewien czas praktykę w powiecie Olhopolskim, skąd m.in. przesyłał pracującemu w Krzemieńcu bratu Karolowi wiadomości o występujących tam chorobach zakaźnych ${ }^{12}$, a 2 lipca 1844 r. został przyjęty w poczet członków Towarzystwa Lekarskiego Warszawskiego ${ }^{13}$ jako korespondent z Włodzimierza Wołyńskiego ${ }^{14}$. W gronie absolwentów Uniwersytetu Wileńskiego, gdzie rozpoczął studia w roku akademic-

${ }^{2}$ P. Szarejko, Stownik biograficzny lekarzy XIX wieku, t. I, Polskie Towarzystwo Lekarskie, Warszawa 1991, s. 255.

${ }^{3}$ Za: M. Danilewiczowa, Życie naukowe dawnego Liceum Krzemienieckiego, Warszawa 1937, s. 62.

${ }^{4}$ K. Estreicher, Bibliografia polska XIX stulecia, t. II G-L, Drukarnia Uniwersytetu Jagiellońskiego, Kraków 1874, s. 317.

5 Tamże.

${ }^{6}$ Wielka Encyklopedya Powszechna Ilustrowana, t. XXXIII-XXXIV, Dr. A.T. Jezierskiego, Warszawa 1903, s. 321.

7 Tamże.

${ }^{8}$ St. Kośmiński, Słownik lekarzów polskich, Nakład autora, Warszawa 1883, s. 206.

9 Samuela Orgelbranda Encyklopedjia Powszechna, t. VIII, Druk. S. Orgelbranda Synów, Warszawa 1900, s. 7.

${ }^{10}$ P. Szarejko, dz. cyt., s. 255.

${ }^{11}$ W. Lisowski, Polska służba zdrowia w powstaniach narodowych, t. I, BELLONA, Warszawa 2006, s. 124-125.

${ }^{12}$ K. Kaczkowski, Lekcje hygieny, czyli nauki zachowania zdrowia, t. II, Druk. N. Glücksberga, Warszawa 1828, s. 166.

${ }^{13}$ P. Szarejko, dz. cyt., s. 255.

14 „Pamiętnik Towarzystwa Lekarskiego Warszawskiego”, Serya II, t. I, poszyt I, Warszawa 1851, s. 137. 
kim 1825/1826 i uzyskał dyplom lekarza I klasy, pozwalający ubiegać się o stopień doktora medycyny, wymienia go w swoim zestawieniu Józef Bieliński ${ }^{15}$. Podaje jednocześnie tytuł jego pracy o cholerze, przy czym trudno jest ustalić, czy była to bezpośrednio dysertacja stanowiąca tezę doktoratu, czy samodzielny tekst, gdyż w zestawieniu doktorantów przy nazwisku Michała Kaczkowskiego podaje jeszcze liczącą 50 stron pracę De hydrophobia ${ }^{16}$, poświęconą wściekliźnie, którą przedłożył 20 marca 1829 r. $^{17}$, i która została wydana w Wilnie w tym samym okresie ${ }^{18}$. Ta pierwsza praca Michała Kaczkowskiego zachowała się w zbiorach biblioteki Litewskiej Akademii Nauk w Wilnie $^{19}$. Niewiele więcej informacji znaleźć można w pracy Franciszka Giedroycia, który dodaje, iż był „,adiunktem kliniki terapeutycznej w Warszawie, wstąpił do wojska 16. II. 1831 roku, był lekarzem naczelnym w domu Krzemińskiego, w kwietniu wysłany do Radomia na lekarza dyrygującego szpitalem wojskowym, od czerwca był kierownikiem ambulansów sztabu głównego w stopniu lekarza sztabowego, 11 sierpnia 1831 roku ozdobiony złotym krzyżem Virtuti Militari”"20, a jak dodaje jeszcze Tadeusz Oksza-Orzechowski ${ }^{21}$, w czasie wojny polsko-rosyjskiej często bywał również oddelegowywany do lazaretów, w których przebywali chorzy na cholerę, i przypuszczalnie kierował pierwszą komisją wojskową, która została wysłana do Zamościa natychmiast po wybuchu epidemii na terenie twierdzy ${ }^{22}$. Krótką, kilkuwersową notatkę dotyczącą tych wydarzeń, a ponadto podającą, jako datę urodzenia Michała Kaczkowskiego, rok 1808, zamieścił Tadeusz Zakrzewski w Polskim Stowniku Biograficznym w akapicie po biogramie Karola Kaczkowskiego ${ }^{23}$.

Współcześnie, poza danymi, które opublikował w cytowanej już pracy Piotr Szarejko ${ }^{24}$, postać Michała Kaczkowskiego została praktycznie zupełnie zapomniana i m.in. nie wspomina go internetowa

15 J. Bieliński, Stan nauk lekarskich za czasów Akademii Medyko-Chirurgicznej Wileńskiej bibliograficznie przedstawiony, Wyd. Towarzystwa Lekarskiego Warszawskiego, Warszawa 1888, s. 220.

16 Tamże, s. 233.

17 P. Szarejko, dz. cyt., s. 255.

${ }^{18}$ K. Estreicher, Bibliografia polska XIX stulecia, t. II G-L..., s. 318.

${ }^{19}$ Nr. kat. L-19/399.

${ }^{20}$ Fr. Giedroyć, Stużba zdrowia w dawnem wojsku polskim, Departament Sanitarny, Warszawa 1927, s. 432.

${ }^{21}$ Wspomnienie z papierów pozostałych..., dz. cyt., s. 263.

${ }^{22}$ Tamże.

${ }^{23}$ „Polski Słownik Biograficzny”, T. II Jar-Kap, s. 376.

${ }^{24}$ P. Szarejko, dz. cyt., s. 255. 
wersja Polskiego Słownika Biograficznego ${ }^{25}$, która również nie podaje informacji o postaci Karola Kaczkowskiego. Jak widać, po blisko 200 latach nie zostało wiele.

A był on młodszym bratem właśnie Karola, najpierw od $1822 \mathrm{r}$. lekarza ${ }^{26}$, a następnie profesora Liceum Krzemienieckiego, od lutego 1830 r. zaś profesora terapii ogólnej fakultetu medycznego Uniwersytetu Warszawskiego ${ }^{27}$, później podczas wojny polsko-rosyjskiej $1831 \mathrm{r}$. generalnego sztabslekarza wojska polskiego. Do Warszawy Michał Kaczkowski przyjechał na zaproszenie starszego brata, najprawdopodobniej późną wiosną $1830 \mathrm{r}^{28}$ po czym na przełomie $1830 / 1831 \mathrm{r}$. podjął pracę w uniwersyteckiej klinice terapeutycznej ${ }^{29}$.

\section{Zainteresowanie Michała Kaczkowskiego epidemią cholery}

Plan, schemat, względnie pierwotną wersję tekstu musiał Michał Kaczkowski przygotować jeszcze przed przyjazdem do stolicy. Pracował nad tym i gromadził niezbędne notatki w Wilnie pod koniec $1829 \mathrm{r}$. Najprawdopodobniej działo się to równolegle z powstawaniem jego pracy doktorskiej. Na postawienie takiego wniosku pozwala wzmianka w monografii Józefa Bielińskiego, gdyż w rozdziale poświęconym $P a-$ tologji ogólnej, semiotyce i epidemiologii ${ }^{30}$ wspomina on o zainteresowaniu się przez Michała Kaczkowskiego problemem epidemii cholery szerzącej się na południowo-wschodnich terenach Rosji. Tematyka ta znajdowała również żywe zainteresowanie w środowisku medycznym skupionym wokół Uniwersytetu Wileńskiego. Sprzyjało temu zaprezentowanie przez Andrzeja Wysokińskiego ${ }^{31}$, który zetknął się $\mathrm{z}$ tą chorobą na Kaukazie, gdzie pracował od 1822 r., m.in. jako lekarz w szpitalu wojskowym w Tyflisie (obecnie Tbilisi), swoich doniesień z podejmowanych tam działań zapobiegawczych i terapeutycznych. Działał przez pewien czas na pograniczu Persji, gdzie mógł swoje doświadczenia porównywać i konsultować z lekarzami brytyjskimi, którzy z cholerą zetknęli się w Indiach. Kolejnym powodem było opu-

25 http://www.ipsb.nina.gov.pl:8080/Search/Type,Biography/Phrase,Kaczkowski\% 20Micha\%C5\%82/ [dostęp: 30.04.2020].

${ }^{26}$ W. Lisowski, Generał profesor Karol Kaczkowski, MON, Warszawa 1986, s. 21.

27 „Gazeta Polska”, Warszawa, 22 lutego 1830 r., nr 50, s. 1.

${ }^{28}$ „Wspomnienie z papierów pozostałych po śp. Karolu Kaczkowskim generał sztab-lekarzu wojsk polskich ułożył Tadeusz Oksza-Orzechowski”, t. II, Gubrynowicz i Schmidt, Lwów 1876, s. 224.

${ }^{29}$ Tamże, s. 235.

${ }^{30}$ J. Bieliński, dz. cyt., s. 216.

${ }^{31}$ Tamże, s. 220. 
blikowanie tekstu Feliksa Rymkiewicza i Ignacego Fonberga, który ukazał się drukiem najprawdopodobniej w pierwszej połowie $1830 \mathrm{r}$., a dotyczył tej samej problematyki ${ }^{32}$. Sam autor, już na wstępie, również powoływał się na doniesienia Andrzeja Wysokińskiego ${ }^{33}$, a także wspominał działania wileńskich lekarzy związanych z fakultetem medycznym uniwersytetu, m.in. Adolfa Abichta, Feliksa Rymkiewicza, Józefa Mianowskiego i Korzeniowskiego (tu niestety imię jest trudne do jednoznacznego ustalenia, ponieważ było kilku lekarzy noszących to nazwisko, przypuszczalnie w tej kwestii chodziło o Józefa Korzeniowskiego), którzy również zajmowali się tą problematyką, oraz o czym nie omieszkał wspomnieć Michał Kaczkowski - „przedsiębrali z narażeniem własnego życia podróż do miejsc najbardziej chorobą zajętych" 34 . Kontynuował dalej swoją pracę już w stolicy, a mając dobre, najnowsze materiały, przypuszczalnie pragnął wygłosić referat w Towarzystwie Lekarskim Warszawskim. Temat ten z pewnością wzbudziłby szerokie zainteresowanie, ponieważ, jak pisze w swojej monografii Józef Peszke, „pod koniec roku [w domyśle - 1830] zaczęto się gorliwie zajmować cholerą panującą już wówczas nagminnie w Rosji” ${ }^{35}$ i zagadnieniu temu zostało poświęcone jedno z jesiennych posiedzeń, podczas którego głos w dyskusji zabierali m.in. Franciszek Brandt, Ignacy Fijałkowski oraz Jan Fryderyk Wilhelm Malcz ${ }^{36}$.

\section{0 poznawaniu, sposobach zapobieżenia i leczeniu choroby cholera morbus zwanej}

Praca Michała Kaczkowskiego jest drukiem wydanym w popularnej podówczas „ósemce”, czyli o wymiarach 10,5 × $21 \mathrm{~cm}$. Okładkę zdobi jeden z symboli medyków - wąż owinięty wokół laski Eskulapa. Katalog NUKAT ${ }^{37}$ notuje go w zbiorach Biblioteki Polskiej w Paryżu ${ }^{38}$, Wojewódzkiej Bibliotece Publicznej w Lublinie ${ }^{39}$ oraz z bibliotece Instytutu Historii PAN w Warszawie ${ }^{40}$. Dwa egzemplarze znajdują się

32 Tamże.

${ }^{33}$ M. Kaczkowski, O poznawaniu, sposobach zapobieżenia i leczeniu choroby cholera morbus zwanej, w drukarni Kom. Rząd, Wyzn. Rel. i Ośw., Warszawa 1830, s. (0).

34 Tamże, s. 29.

35 J. Peszke, Stulecie Towarzystwa Lekarskiego Warszawskiego 1820-1920. Dzieje Towarzystwa, cz. I, Nakł. Tow. Lek. Warszawskiego, Warszawa 1931, s. 73.

36 Tamże.

37 http://katalog.nukat.edu.pl/search/query?term_1=0+chorobie + cholera + morbu S+zwanej\&theme=nukat [dostęp: 26.04.2020].

38 BPP FA 7468 II.

39 WBP Lublin Czytelnia Naukowa Nr. kat. 322782 II/L.

${ }^{40}$ IH PAN Nr. kat. I.1973/5/4. 
także w zbiorach Biblioteki Narodowej w Warszawie ${ }^{41}$, przy czym jeden $\mathrm{z}$ nich został przeniesiony $\mathrm{w}$ wersję cyfrową ${ }^{42}$, co zdecydowanie ułatwia szerszy dostęp i zapoznanie się z oryginalnym wydaniem.

Warto zwrócić uwagę na miejsce wydania, jakim była drukarnia znajdująca się pod nadzorem Komisji Rządowej Wyznań Religijnych i Oświecenia Publicznego, a więc instytucji urzędowej. Należy przypuszczać, że była to odpowiedź na pytanie Dyrekcji Policji z 21 listopada $1830 \mathrm{r}^{43}$, po nadejściu z okolic Augustowa informacji o szerzeniu się cholery $\mathrm{w}$ zachodnich prowincjach Rosji i w związku z tym przybliżaniu się zagrożenia do granic Królestwa Polskiego. Niewątpliwie, choć $\mathrm{w}$ treści dokumentu nazwisko Michała Kaczkowskiego nie jest cytowane, korzystali z niej również autorzy opublikowanej w $1831 \mathrm{r}$. broszury Wiadomość o cholerze podana przez Radę Ogólna Lekarska Królestwa Polskiego ${ }^{44}$, co jest szczególnie widoczne w akapitach poświęconych higienie oraz używaniu preparatów chloru jako środka odkażającego.

Ciekawa jest też wzmianka, utrzymana w formie recenzji, którą zamieścił Ludwik Gąsiorowski w trzecim tomie swojej monografii Zbiór wiadomości do historyi sztuki lekarskiej w Polsce, prócz podania nazwiska autora i tytułu, prezentując pokrótce kolejne rozdziały, oraz zaznaczając środki lecznicze, które zostały przy tym omówione ${ }^{45}$. W tej krótkiej notatce ważna jest również informacja o kontaktach Andrzeja Wysokińskiego, na którego zapiski powołuje się Michał Kaczkowski, z lekarzami angielskimi ${ }^{46}$. Można wysnuć przypuszczenie, że jej treść, w czasie nasilających się, a przede wszystkim nawracających epidemii cholery w latach 30 . XIX w., na równi z wydaną w tym samym roku w Wilnie wzmiankowaną już pracą Feliksa Rymkiewicza i Ignacego Fonberga $O$ cholerze $i$ sposobach oczyszczania powietrza $w$ czasie panuiacey zarazy ${ }^{47}$, stanowiła jeden z poradników dla lekarzy, a przede wszystkim władz przy wydawaniu odpowiednich zarządzeń higieniczno-sanitarnych.

41 BN Nr. kat. 2.003.873 A.

42 https://polona.pl/item/o-poznawaniu-sposobach-zapobiezenia-i-leczeniu-choroby-cholera-morbus-zwanej,NjEzOTk1ODc/6/\#info:metadata [dostęp: 22.04.2020].

43 Fr. Giedroyć, Rada lekarska Księstwa Warszawskiego i Królestwa Polskiego (1809-1867), Księgarnia E. Wende, Warszawa 1913, s. 538.

44 Tamże, s. 549.

45 L. Gąsiorowski, Zbiór wiadomości do historyi sztuki lekarskiej w Polsce, Nakładem J.K. Żupańskiego, Poznań 1854, s. 442-443.

46 Tamże, s. 443.

47 F. Rymkiewicz, I. Fonberg, $O$ cholerze $i$ sposobach oczyszczania powietrza w czasie panuiacey zarazy, Druk. T. Glücksberga, Wilno 1830. 
Praca Michała Kaczkowskiego z pewnością dała asumpt do dalszych badań nad problematyką epidemii cholery oraz samą chorobą. Brak jest co prawda jednoznacznych odnośników bibliograficznych, ale z pewnością była znana Janowi Fryderykowi Wilhelmowi Malczowi, autorowi powstałej rok później publikacji poświęconej tej tematyce, a mianowicie: $O$ cholerze indyjskiej epidemicznej ${ }^{48}$, oraz Zygmuntowi H. Terleckiemu, gdy pisał swoją De cholera $^{49}$. Korzystał $\mathrm{z}$ niej bez wątpienia Ludwik Bierkowski, przygotowując obszerny cykl - zachowanych do dziś w manuskrypcie znajdującym się w zbiorach Biblioteki Jagiellońskiej w Krakowie - wykładów zatytułowanych $O$ cholerze ${ }^{50}$. Musiał również zapoznać się z jej treścią i Karol Marcinkowski, szczególnie w czasie borykania się z epidemią tej choroby, która nawiedziła Wielkopolskę i Poznań w 1837 r. ${ }^{51} \mathrm{Z}$ pewnością znali dziełko Michała Kaczkowskiego członkowie Towarzystwa Lekarskiego Warszawskiego, dość często poruszający problemy związane z występowaniem tej choroby podczas swoich posiedzeńn ${ }^{52}$.

Zasadniczy tekst został poprzedzony krótkim wprowadzeniem, w którym prócz odniesień do pracy wzmiankowanego już Andrzeja Wysokińskiego, a także wytycznych, które ogłoszone zostały w formie oficjalnych zaleceń rządowych opublikowanych przez władze rosyjskie w Petersburgu, można znaleźć nawiązanie do znanych już publikacji naukowych. Były to przede wszystkim prace Christopha Wilhelma Hufelanda, autora m.in. wydanego w 1819 r. Conspectus morborum secundum ordines naturales adjunctis characteribus specificis diagnosticis seu signis pathognomicis ${ }^{53}$, oraz Georga Hartona Gersona. Ten ostatni zajmował się m.in. problemami epidemii panujących w szpitalach wojskowych podczas kampanii napoleońskich przede wszystkim na terenie Hiszpanii, gdzie w okolicach Kadyksu zetknięto się nie tylko z cholerą, ale także z dżumą, o czym donosił Jean-Pierre $\mathrm{Gama}^{54}$, a także po bitwie pod Waterloo, w tym przede wszystkim

\footnotetext{
${ }^{48}$ J.Fr.W. Malcz, O cholerze indyjskiej epidemicznej, Druk. Gałęzowskiego i Komp., Warszawa 1831.

${ }^{49}$ Z.H. Terlecki, De cholera, Typ. St. Gieszkowski, Cracoviae 1833.

${ }^{50}$ L. Bierkowski, $O$ cholerze, Nr. kat. BJ Rkp. 6409 IV.

${ }^{51}$ L. Gąsiorowski, dz. cyt., s. 435.

${ }^{52}$ M.in. posiedzenie z dnia 21.08.1852 r. Tu za: „Stulecie Towarzystwa Lekarskiego Warszawskiego 1820-1920. Dzieje Towarzystwa część I napisał Józef Peszke”, s. 261.

${ }_{53}$ Ch.W. Hufeland, Conspectus morborum secundum ordines naturales adjunctis characteribus specificis diagnosticis seu signis pathognomicis. In usum auditorum, Ausgebung F. Dümler, Berlin 1819.

${ }^{54}$ Za: R. Bielecki, Wielka armia Napoleona, BELLONA, Warszawa 2004, s. 157.
} 
zakażeniami określanymi współcześnie mianem zgorzeli gazowej ${ }^{55}$. Całość kończy podpis oraz ważna dla lokalizacji miejsca powstania informacja: „pisałem w Warszawie 14 listopada 1830 roku”, czyli praktycznie tuż po dotarciu do Komisji Rządowej Spraw Wewnętrznych pierwszego raportu o pojawieniu się zagrożenia epidemicznego, co miało miejsce 2 listopada $1831 \mathrm{r}^{57}$

Dalszy ciąg tekstu podzielony został na mniejsze, samodzielne rozdziały wyróżnione oddzielnymi tytułami drukowanymi majuskułą:

1) Historya choroby cholera morbus (s. 3-7) - wymienione tu zostały obszary, w których zaobserwowano po raz pierwszy występowanie cholery, poczynając od XVII w., oraz jej szerzenie się w Europie m.in. na terenie Anglii, Francji oraz w basenie Morza Śródziemnego, szczególnie w Wenecji, gdzie odnotowywane przypadki wiązano z przybywaniem statków ze Wschodu, co skłoniło władze tego miasta do nakładania długich, sięgających 40 dni - stąd nazwa - okresów kwarantanny w podległych jej portach. Jednak w początkach XIX w. główny obszar epidemiczny stanowiły przede wszystkim Indie, ówczesna Persja oraz wybrzeża Morza Kaspijskiego, w tym Astrachań, skąd najprawdopodobniej choroba dotarła na teren Rosji, szerząc się wzdłuż szlaków handlowych Wołgi i Donu.

2) Symptomata (s. 7-10) - podane zasadnicze objawy, wśród nich bóle głowy, biegunka, wymioty oraz silne bóle brzucha. Choroba, co podkreślił Michał Kaczkowski, ma przebieg bardzo gwałtowny, dlatego „niekiedy chorzy zaledwie zdołali opowiedzieć swoje cierpienia a już w kilka chwil potem śmierci podlegli" 58 , a „nierzadkie są na koniec przykłady śmierci w sześć godzin po zjawieniu się choroby”59. Zaznaczył przy tym, że: „na twarzy chorego całą wielkość jego cierpień wyczytać można, przedstawia bowiem smutek nadzwyczajny, oczy są wklęsłe, na wpół otwarte, mało ruchome i krwią zalane; głowa zaś jakby wielkim, jakim ciężarem przywalona, na piersiach lub ramionach ciągle spoczywa" ${ }^{60}$. W tym miejscu warto zwrócić uwagę na cytowaną przez Michała Kaczkowskiego obserwację dokonaną przez Andrzeja Wysokińskiego, a dotyczącą

${ }_{55}$ G.H. Gerson, Ueber den Hospitalbrand, nach eignen während des spanischen Befreyungskriegs und in Belgien gemachten Erfahrungen, Ausgebung B.G. Hoffmann \& A. Camps, Hamburg 1817.

${ }^{56}$ M. Kaczkowski, dz. cyt., s. (0).

57 Fr. Giedroyć, Rada lekarska Księstwa Warszawskiego i Królestwa Polskiego (1809-1867)..., s. 538.

${ }^{58}$ M. Kaczkowski, dz. cyt., s. 9.

${ }^{59}$ Tamże, s. 10.

${ }^{60}$ Tamże, s. 8. 
znacznego zagęszczenia oraz ciemnego zabarwienia krwi, co było następstwem błyskawicznie narastającego odwodnienia organizmu chorego.

3) Rozbiór anatomiczny (s. 10-11) - pomimo ryzyka zakażenia dokonywane były sekcje zwłok zmarłych na cholerę, lecz niestety nie dawało to pozytywnych rezultatów w „wyśledzeniu bliższej przyczyny choroby"61, jednak za symptomatyczne uznano zmiany w mięśniach, które były „rozwolnione” ${ }^{2}$, oraz efekt wspomnianego już znacznego zagęszczenia krwi, przede wszystkim uwidaczniający się w naczyniach trzewnych oraz mózgowych.

4) Przyczyny (s. 11-14) - w akapicie tym Michał Kaczkowski wyraźnie zaznacza, że zasadniczy czynnik patologiczny wywołujący tę chorobę nie jest jeszcze znany. Dodaje przy tym, iż choroba najczęściej dotyka terenów z bogatą szatą roślinną, dużą ilością wody, jak również tam, gdzie występują duże skupiska ludzkie, panuje ciasnota oraz głód zmuszający do odżywiania się „niedojrzałymi owocami"63. Istotną wskazówką, jaką zamieścił, było m.in. to, że cholera szerzy się niezależnie od pór roku, czego najlepszym przykładem była epidemia w Orenburgu, do której doszło w czasie zimy.

5) Poznanie choroby (s. 14-15) - po raz drugi zostały tu wymienione wszystkie podstawowe objawy cholery.

6) Rokowanie (s. 15-17) - już w jednym z pierwszych wersów choroba została zaliczona do kategorii „,chorób koniecznie śmiercią grożących" ${ }^{64}$, następnie zaś zostały opisane symptomy wskazujące na bliski zgon, wśród nich śpiączka oraz „zmarszczenie skóry na dłoniach i podeszwach"65 będące skutkiem szybko narastającego odwodnienia organizmu. W tym rozdziale Michał Kaczkowski porównał spostrzeżenia dwóch lekarzy. Pierwszym z nich był Anglik Frederick Corbyn pracujący na terenie brytyjskich kolonii w Indiach i Persji, który w 1828 r. ogłosił pracę poświęconą chorobom związanym z panującym tam klimatem ${ }^{66}$, w której również zajmował

${ }^{61}$ Tamże, s. 10 .

${ }^{62}$ Tamże, s. 11

${ }^{63}$ Tamże, s. 12.

${ }^{64}$ Tamże, s. 15.

${ }^{65}$ Tamże, s. 16.

${ }^{66}$ F. Corbyn, Management and diseases of infants, under the influence of the climate of India being instructions to mothers and parents, in situations where medical aid is not to be obtained, and a guide to medical men, inexperienced in the nursery and the treatment of tropical infantile disease. Illustrated by coloured plates, Messrs. Thacker \& Co., St. Andrew's library, Calcutta 1828. 
się cholerą. Drugim - Andrzej Wysokiński, i były to przede wszystkim informacje zawarte w jego pracy doktorskiej, którą obronił na Uniwersytecie Wileńskim w 1828 r., zatytułowanej De cholera epidemica indorum ${ }^{67}$. Nie omieszkał przy tym zaznaczyć, że wyniki obserwacji poczynionych przez tych lekarzy znacząco różnią się od siebie. Pierwszy konstatował, iż w ostatnim okresie tuż przed zgonem chorzy są wyjątkowo pobudzeni, natomiast drugi stwierdzał coś wręcz przeciwnego, pisząc nawet, iż „od wszelkich cierpień byli wolni, owszem nawet sami zapewniali, że się lepiej mają" ${ }^{68}$. Leczenie (s. 17-29) - jest to najdłuższy rozdział, który dodatkowo został jeszcze podzielony na dwie części oznaczone w pierwszym akapicie literami:

a) leczenie choroby już rozwiniętej w organizmie określone mianem „cura therapeutica” 69

b) środki zapobiegawcze w celu ochrony ludzi zdrowych, czyli „prophylaxis"

Odnośnie do pierwszej, Michał Kaczkowski podaje najrozmaitsze środki stosowane w trakcie choroby, odwołując się do danych zgromadzonych przez Andrzeja Wysokińskiego oraz wielu lekarzy angielskich, wśród nich wzmiankowanego już Fredericka Corbyna, a także Rosjan, tu m.in. Papyrowa ${ }^{71}$. Było to przede wszystkim postępowanie objawowe - w celu zahamowania biegunki i wymiotów podawano preparaty na bazie opium, przede wszystkim-nalewkę Sydenhama ${ }^{72}$ i inne preparaty zawierające ten składnik, które zalecali wszyscy cytowani przez Michała Kaczkowskiego lekarze angielscy. Ze względu na zawartość kory cynamonowca wykazywała ona również pewne działanie rozkurczowe. Frederick Cobryn do nalewki Sydenhama dodaje jeszcze kalomel ${ }^{73}$. Wśród szczególnie preferujących ten specyfik Michał Kaczkowski wymienia nazwiska Fredericka Corbyna, Milwooda, Taylora, jak również Andersona - przypuszczalnie cytując je za pracą

${ }^{67}$ J. Bieliński, Stan nauk lekarskich za czasów Akademii Medyko-Chirurgicznej Wileńskiej bibliograficznie przedstawiony..., s. 220.

${ }^{68}$ M. Kaczkowski, dz. cyt., s. 16.

${ }^{69}$ Tamże, s. 17.

70 Tamże.

${ }^{71}$ Tamże, s. 20.

72 Nalewka Sydenhama zwana inaczej laudanum, mieszanina opium, mocnego wina oraz m.in cynamonu i goździków. Za: „Formulaire pharmaceutique à l'usage des hôpitaux militaires de la République française", l'Imprimerie de la Departament de Guerre, Paris l'An II Republique Française, s. 40.

${ }^{73}$ M. Kaczkowski, dz. cyt., s. 19. 
Andrzeja Wysokińskiego. Generalnie „lekarze angielscy”74 ordynowali „opium w powidełkach jakoż mieszają oni 2 gran [0,124 g] opium z 15 merkuriuszu słodkiego [jeden z synonimów kalomelu ${ }^{75}-\mathrm{w}$ druku pierwsza cyfra jest mniejsza od drugiej, w związku z tym nie wiadomo, czy na pewno chodzi tu o 15 granów, - jeśli tak to: 9,3 g, co jest dość dziwne, gdyż dawka lecznicza tego specyfiku według Christopha Wilhelma Hufelanda wynosiła od 1 do 3 granów ${ }^{76}$, najprawdopodobniej chodziło tutaj o 1,5 grana, czyli ok. 0,93 g] z dwoma i pół drachmami [7,5 g.] miodu i taką mieszaniną smarują język, przez co chory stopniowo połyka lekarstwo" "77. Swoisty sposób postępowania zalecał Astley Douglas, który do preparatów opium i kalomelu dodawał jeszcze kleik ze specjalnie przygotowanej „bułki owsianej”78. Zapisy stosowanych specyfików wskazują też na to, iż Michał Kaczkowski musiał znać również monografię Pierre'a Françoisa Keraudena, podówczas naczelnego lekarza floty francuskiej, poświęconą cholerze ${ }^{79}$, albowiem jego nazwisko również zamieścił, dodając przy tym, że zalecał on „brać opium z eterem siarczanym”80.

$\mathrm{W}$ celu uśmierzenia jednego $\mathrm{z}$ dominujących objawów choroby, jakim były wymioty, prócz opium również stosowano „potio Riverii" ${ }^{81}$ zalecane m.in. przez Fuchsa pracującego w Kazaniu. Była to mieszanka o następującym składzie: „Kalii carbonici, Succi citrici, Aquae Menthae piperitae, Aquuae Foeniculi, Syrupi Althae"82 i znana również pod nazwą „potio Riverdiana”"3, dość powszechnie znana i wzmiankowana w Przepisach lekarstw dla Szpitalów Woyska Polskiego wydanych $\mathrm{w}$ Warszawie w $1810 \mathrm{r}^{84}$

Nieznana choroba zmusiła do poszukiwania nowych metod terapeutycznych i o jednej z nich również wspominał Michał Kaczkowski, opisując sposób postępowania Jana Chlebnikowa, który zalecał poda-

${ }^{74}$ Tamże, s. 20.

75 Ch.W. Hufeland, Conspectus materiae medicae secundum ordines naturales in usum auditorum, Apud Dümler, Berolini 1828, s. 91.

${ }_{76}$ Tamże, s. 105.

77 M. Kaczkowski, dz. cyt., s. 20.

78 Tamże.

${ }^{79}$ P.Fr. Keraudren, Du cholera morbus de l'Inde ou mordechi, Imprimerie Royale, Paris 1824.

${ }^{80}$ M. Kaczkowski, dz. cyt., s. 19.

${ }^{81}$ Tamże, s. 22.

82 Tamże.

83 „Przepisy lekarstw dla Szpitalów Woyska Polskiego. Dzieło tłomaczone z języka francuzkiego...", Warszawa 1810, s. 26.

${ }^{84}$ Tamże. 
wanie magnezji, okłady z rozgrzanego siana oraz zażywanie nalewki Hoffmana $^{85}$ i żywicy gwajakolowej rozpuszczonej w araku ${ }^{86}$.

Zdecydowanie bardziej interesująca jest część druga, w której Michał Kaczkowski zajął się środkami zapobiegającymi rozprzestrzenianiu się choroby. Odwoływał się tu do oficjalnych zaleceń Towarzystwa Lekarskiego Petersburskiego, które dotyczyły:

a) zaprzestania jakichkolwiek kontaktów z obszarem, na którym wystąpiła cholera,

b) starannej izolacji chorych,

c) miejsc przeznaczonych na szpitale, które powinny znajdować się na otwartej przestrzeni,

d) unikania miejsc podmokłych oraz ciasnoty i wilgoci w mieszkaniach.

Tymi samymi zasadami powinno również kierować się wojsko przy wyznaczaniu tymczasowych kwater w miejscach przemarszu. Pozostałe zalecenia dotyczą:

e) koniecznego ograniczenia spożywania pewnych pokarmów, a mianowicie: ,piwa kwaskowatego, kwasu niewystałego ${ }^{87}$ mussującego, mleka kwaśnego, fruktów niedojrzałych"88,

f) chronienia się przed przeziębieniem.

Bardzo istotnym, choć podanym już wcześniej zaleceniem było „obmywanie ciała rozciekiem chlorku wapnia - Chloruretum calcis" ${ }^{\prime \prime}$.

\section{Podsumowanie}

Michał Kaczkowski, przygotowując swój tekst, zdawał sobie doskonale sprawę, iż wiedza o samej cholerze, jak i o środkach zapobiegawczych jest jeszcze bardzo skromna. Dał temu zresztą wyraz w zakończeniu, pisząc: „ściślejsze kiedyś poznanie natury choroby odkryje zapewne dzielniejsze w swych zbawiennych skutkach lekarstwa"90. Jednak wskazał drogę, przede wszystkim swojemu starszemu bratu Karolowi, do podejmowania w czasie walki z epidemią, która nawie-

${ }^{85}$ Nalewka Hoffmana zwana często eliksirem Hoffmana. Preparat ten, zawierający proporcjonalnie 2 części alkoholu oraz 1 część eteru, został sporządzony po raz pierwszy w latach 30. XVIII w. przez Fr. Hoffmanna. Za: Fr. Hoffmann La médecine raisonnée de M. Fr. Hoffmann. Premier Médecindu Roi de Prusse, vol. IV, Paris Chez Briasson 1739, s. 410-436.

${ }^{86}$ M. Kaczkowski, dz. cyt., s. 24-25.

${ }^{87}$ Przypuszczalnie chodziło tu o kwas chlebowy bądź też kwas z soku brzozowego.

${ }^{88}$ M. Kaczkowski, dz. cyt., s. 27.

${ }^{89}$ Tamże, s. 22.

90 Tamże, s. 28. 
dziła Królestwo Polskie w 1831 r., szybkich i skutecznych działań tak $\mathrm{w}$ wojsku ${ }^{91}$, jak i dla ochrony ludności cywilnej ${ }^{92}$. Wspierał go zresztą wówczas osobiście. Pomimo swej szczupłości praca przygotowana jest z niezwykłą starannością, napisana językiem komunikatywnym i zarazem zwięzłym. Dużo mówi o samym autorze i jego systematyczności w gromadzeniu danych i obserwacji. Mimo ograniczonych możliwości oraz jednak peryferyjnego położenia Wilna w stosunku do naukowych centrów ówczesnej Europy umiał wykorzystać dostępne mu teksty i materiały, jak również z pewnością osobiste kontakty z lekarzami, którzy zetknęli się z cholerą panującą dość powszechnie wzdłuż południowych rubieży Rosji.

Można z niej również wnioskować o poziomie wykształcenia autora, który prócz niejako obowiązkowej dla medyków łaciny swobodnie posługiwał się językiem francuskim, a nie jest wykluczone, że i angielskim, co w owych czasach nie było tak powszechne.

Czas - 190 lat - sprawił, że treść uległa częściowej dezaktualizacji, ustąpiła miejsca nowym koncepcjom diagnostycznym i terapeutycznym, których zaistnienie autor przeczuwał, ale pewne ogólne zasady higieniczne do dziś nie straciły na znaczeniu. I może gdy sięgamy po nie, warto przytoczyć słowa Czesława Miłosza: „nasza praca przypomina pracę prządki, a myśli wysnute przez poprzedników nie giną"93, albowiem ową nić, w tym wypadku naukową, ktoś zaczął snuć jako pierwszy.

\section{Bibliografia}

Bielecki R., Wielka armia Napoleona, BELLONA, Warszawa 2004.

Bieliński J., Stan nauk lekarskich za czasów Akademii Medyko-Chirurgicznej Wileńskiej bibliograficznie przedstawiony, Wyd. Towarzystwa Lekarskiego Warszawskiego, Warszawa 1888.

Bierkowski L., O cholerze, Nr. kat. BJ Rkp. 6409 IV.

Corbyn F., Management and diseases of infants, under the influence of the climate of India being instructions to mothers and parents, in situations where medical aid is not to be obtained, and a guide

${ }_{91}$ M. Ropek, Karol Kaczkowski, jako lekarz i obywatel kraju, „Rozprawy na stopień doktora medycyny b. wychowanków szkoły podchorążych sanitarnych”, nr 7, Warszawa 1938, s. 63-64.

${ }_{92} \mathrm{Tu}$ przede wszystkim: K. Kaczkowski, $O$ używaniu preparatów chloru przeciw zarazom i szkodliwym wyziewom, Drukarnia Rządowa, Warszawa 1831.

${ }_{93}$ Cz. Miłosz, Widzenia nad Zatoka San Francisco, GŁOS, Warszawa 1980 [brak paginacji]. 
to medical men, inexperienced in the nursery and the treatment of tropical infantile disease. Illustrated by coloured plates, Messrs. Thacker \& Co., St. Andrew's library, Calcutta 1828.

Danilewiczowa M., Życie naukowe dawnego Liceum Krzemienieckiego, Warszawa 1937.

Estreicher K., Bibliografia polska XIX stulecia, t. II G-L, Drukarnia Uniwersytetu Jagiellońskiego, Kraków 1874.

„Formulaire pharmaceutique à l'usage des hôpitaux militaires de la République française", l'Imprimerie de la Departament de Guerre, Paris l'An II Republique Française.

„Gazeta Polska”, Warszawa, 22 lutego 1830 r., nr 50.

Gąsiorowski L., Zbiór wiadomości do historyi sztuki lekarskiej w Polsce, Nakładem J.K. Żupańskiego, Poznań 1854.

Gerson G.H., Ueber den Hospitalbrand, nach eignen während des spanischen Befreyungskriegs und in Belgien gemachten Erfahrungen, Ausgebung B.G. Hoffmann \& A. Camps, Hamburg 1817.

Giedroyć Fr., Rada lekarska Księstwa Warszawskiego i Królestwa Polskiego (1809-1867), Księgarnia E. Wende, Warszawa 1913.

Giedroyć Fr., Stużba zdrowia w dawnem wojsku polskim, Departament Sanitarny, Warszawa 1927.

Hoffmann Fr., La médecine raisonnée de M. Fr. Hoffmann. Premier Médecindu Roi de Prusse, vol. IV, Paris Chez Briasson 1739.

Hufeland Ch.W., Conspectus morborum secundum ordines naturales adjunctis characteribus specificis diagnosticis seu signis pathognomicis. In usum auditorum, Ausgebung F. Dümler, Berlin 1819.

Hufeland Ch.W., Conspectus materiae medicae secundum ordines naturales in usum auditorum, Apud Dümler, Berolini 1828.

Kaczkowski K., Lekcje hygieny, czyli nauki zachowania zdrowia, t. II, Druk. N. Glücksberga, Warszawa 1828.

Kaczkowski K., O używaniu preparatów chloru przeciw zarazom i szkodliwym wyziewom, Drukarnia Rządowa, Warszawa 183.

Kaczkowski M., O poznawaniu, sposobach zapobieżenia i leczeniu choroby cholera morbus zwanej, w drukarni Kom. Rząd, Wyzn. Rel. i Ośw., Warszawa 1830.

Keraudren P.Fr., Du cholera morbus de l'Inde ou mordechi, Imprimerie Royale, Paris 1824.

Kośmiński St., Słownik lekarzów polskich, Nakład autora, Warszawa 1883.

Lisowski W., Generat profesor Karol Kaczkowski, MON, Warszawa 1986. 
Lisowski W., Polska stużba zdrowia w powstaniach narodowych, t. I, BELLONA, Warszawa 2006.

Malcz J.Fr.W., O cholerze indyjskiej epidemicznej, Druk. Gałęzowskiego i Komp., Warszawa 1831.

Miłosz Cz., Widzenia nad Zatoka San Francisco, GŁOS, Warszawa 1980.

Wspomnienie z papierów pozostałych po ś.p. Karolu Kaczkowskim generat sztab-lekarzu wojsk polskich ułożyt Tadeusz Oksza-Orzechowski, t. II, Gubrynowicz i Schmidt, Lwów 1876.

„Pamiętnik Towarzystwa Lekarskiego Warszawskiego”, Serya II, t. I, poszyt I, Warszawa 1851.

Peszke J., Stulecie Towarzystwa Lekarskiego Warszawskiego 1820 1920. Dzieje Towarzystwa, cz. I, Nakł. Tow. Lek. Warszawskiego, Warszawa 1931.

„Polski Słownik Biograficzny”, t. II Jar-Kap.

„Przepisy lekarstw dla Szpitalów Woyska Polskiego. Dzieło tłomaczone z języka francuzkiego...”, Warszawa 1810.

Ropek M., Karol Kaczkowski, jako lekarz i obywatel kraju, „Rozprawy na stopień doktora medycyny b. wychowanków szkoły podchorążych sanitarnych", nr 7, Warszawa 1938.

Rymkiewicz F., Fonberg I., O cholerze i sposobach oczyszczania powietrza w czasie panuiqcey zarazy, Druk. T. Glücksberga, Wilno 1830.

Samuela Orgelbranda Encyklopedjia Powszechna, Druk. S. Orgelbranda Synów, Warszawa 1900, t. VIII.

Szarejko P., Słownik biograficzny lekarzy XIX wieku, t. I, Polskie Towarzystwo Lekarskie, Warszawa 1991.

Terlecki Z.H., De cholera, Typ. St. Gieszkowski, Cracoviae 1833.

Wielka Encyklopedya Powszechna Ilustrowana, t. XXXIII-XXXIV, Dr. A.T. Jezierskiego, Warszawa 1903.

\section{Strony internetowe}

http://www.ipsb.nina.gov.pl:8080/Search/Type,Biography/Phrase,Kaczkowski\%20Micha\%C5\%82/.

http://katalog.nukat.edu.pl/search/query?term_1=0+chorobie + cholera + morbus + zwanej\&theme $=$ nukat.

https://polona.pl/item/o-poznawaniu-sposobach-zapobiezenia-i-leczeniu-choroby-cholera-morbus-zwanej,NjEzOTk1ODc/6/\#info:metadata. 